\title{
INTEGRATED MEMBRANE SEPARATION PROCESSES AIMING TO CONCENTRATE AND PURIFY LYCOPENE FROM WATERMELON JUICE
}

\author{
C. S.Oliveira ${ }^{1}$, F. S. Gomes ${ }^{2}$, L. F. M. Silva ${ }^{3}$, R. L. O. Godoy ${ }^{4}$, R. V. Tonon ${ }^{5}$, L. M. C. \\ $\mathrm{Cabral}^{6}$
}

\begin{abstract}
1 - Instituto de Química. Universidade Federal do Rio de Janeiro. CEP: 21941-909, Rio de Janeiro - RJ, Brasil Telefone: 55 (21) 3938-7260 - Fax: 55 (21) 3938-7106 email: (ocassia2004@ gmail.com)

2- Embrapa Agroindústria de Alimentos - Embrapa - CEP: 23020-470 - Rio de Janeiro - RJ - Brasil - Telefone: 55 (21) 3622-9689- Fax: 55 (21) 3622-9713 - e-mail: (flavia.gomes@embrapa.br)

3- Embrapa Agroindústria de Alimentos - Embrapa - CEP: 23020-470 - Rio de Janeiro - RJ - Brasil - Telefone: 55 (21) 3622-9688-Fax: 55 (21) 3622-9713 - e-mail: (luizfernando.menezes @embrapa.br)

4- Embrapa Agroindústria de Alimentos - Embrapa - CEP: 23020-470 - Rio de Janeiro - RJ - Brasil - Telefone: 55 (21) 3622-9774- Fax: 55 (21) 3622-9713 - e-mail: (ronoel.godoy@embrapa.br)

5- Embrapa Agroindústria de Alimentos - Embrapa - CEP: 23020-470 - Rio de Janeiro - RJ - Brasil - Telefone: 55 (21) 3622-9705- Fax: 55 (21) 3622-9713 - e-mail: (renata.tonon@embrapa.br)

6- Embrapa Agroindústria de Alimentos - Embrapa - CEP: 23020-470 - Rio de Janeiro - RJ - Brasil - Telefone: 55 (21) 3622-9705-Fax: 55 (21) 3622-9713 - e-mail: (lourdes.cabral@embrapa.br)
\end{abstract}

\begin{abstract}
The increasingly consumer demand for ingredients obtained from natural sources and sustainable processes represents for the industry the challenge to place on the market innovative products with high added value. Watermelon is known for its high lycopene content, the red pigment with recognized antioxidant properties. This work investigated the integration of microfiltration and diafiltration processes to obtain a low sugar lycopene-rich extract from watermelon juice. Permeate flux, lycopene and sugars content and the antioxidant were used to evaluate the performance of the integrated membrane processes. The average permeate flux of microfiltration/diafiltration process was $69.6 \mathrm{~L} \mathrm{~h}^{-1} \mathrm{~m}^{-2}$. Increases up to 5 and 4 times in lycopene content and antioxidant capacity, respectively, as well as a decrease in sugars concentration of the extract were achieved.
\end{abstract}

KEYWORDS: microfiltration, diafiltration, watermelon, carotenoids, ingredients

RESUMO - A crescente demanda dos consumidores por ingredientes obtidos a partir de fontes naturais e processos sustentáveis representa para a indústria o desafio colocar no mercado produtos inovadores de alto valor agregado. A melancia é conhecida por seu alto teor de licopeno, um pigmento vermelho com reconhecidas propriedades antioxidantes. Este trabalho teve por objetivo investigar a integração dos processos de microfiltração e diafiltração para obtenção um extrato rico em licopeno com baixo teor de açúcares a partir do suco de melancia. O fluxo de permeado, o teor de licopeno, o teor de açúcares e a capacidade antioxidante do extrato foram utilizados para avaliar a eficiência dos processos. O fluxo médio de permeado do processo de microfiltração/diafiltração foi de $69,6 \mathrm{~L} \mathrm{~h}^{-1} \mathrm{~m}^{-2}$. $\mathrm{O}$ teor de licopeno e a capacidade antioxidante do extrato aumentaram em relação ao suco integral, assim como uma redução na concentração foi observada.

PALAVRAS-CHAVES: microfiltração, diafiltração, melancia, carotenoides, corantes, ingredientes 


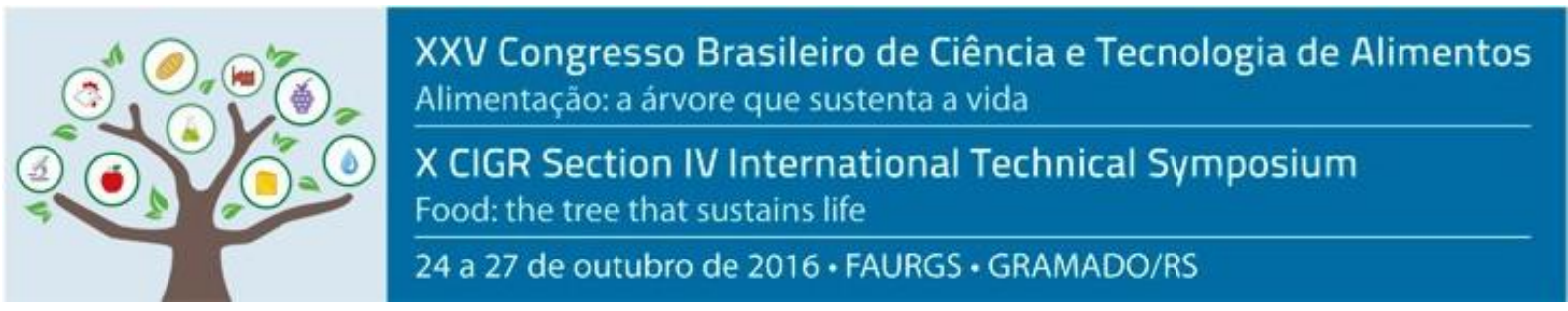

\section{INTRODUCTION}

Watermelon is a plant of great economic and social importance around the world. The estimative for its global production was about 98.2 million ton in 2009, being China, Turkey, Iran and Brazil the main producing countries (FAO, 2014).

The red color of watermelon pulp is due to lycopene, a carotenoid with significant antioxidant properties. Lycopene levels in the range of $47-68 \mathrm{mg} / \mathrm{g}$ fresh fruit have been reported in watermelon (Perkins-Veazie et al, 2001).

In the last years, the consumer's growing concern about maintaining a healthy lifestyle has been outlining changes in the people habits with regards to a healthier, natural and equilibrated diet so that the search for natural ingredients and additives also follow this trend.

Thus, the high productivity and the specific chemical composition of watermelon make it a promising raw material for the production of natural ingredients of high added value.

Although it is not usual finding watermelon industrialized products, juice concentration can produce lycopene-rich products to meet the growing market of natural ingredients, especially colorants and antioxidants, to foods and beverages and, to a lesser extent, cosmetics and medicine, as well as functional supplements that presents an average growth of $15 \%$ per year in Brazil (BRASLINK, 2014).

Compared to conventional thermal concentration processes, membrane technology seems to be a good alternative to minimize the adverse effects of heat (Balyan \& Sarkar, 2016). In general, membrane filtration does not involve phase transition or high temperatures, favoring the maintenance of sensory and functional characteristics of the product and, depending on the selectivity of the membrane, the process can fractionate or concentrate different compounds.

Due to its molecular weight $\left(536.87 \mathrm{gmol}^{-1}\right)$ and the fact that it in vegetable tissues can be tightly bound to proteins and other plant cell structures such as fibers and polysaccharides (Hurst, 2002), lycopene does not permeate microfiltration, ultrafiltration or reverse osmosis membranes, thus, the concentration of this compound from fruit juices by means of membrane separation processes has shown to be a viable process and represents a good alternative for industrial purposes (Gomes et al., 2013).

The membrane processes can still be operated in a diafiltration mode. In this type of process it is possible to obtain a higher purity level of the compound in the same concentration ratio due to the removal of impurities smaller than the membrane porosity. Although it was first studied in 1968, few papers in the literature applied this technique for the purification of bioactive compounds from juice fruits (Simon et al, 2002).

The objective of this study was to evaluate the feasibility of concentration and purification of lycopene from watermelon juice by coupling microfiltration and diafiltration in order to obtain a rich lycopene concentrated extract with high antioxidant capacity.

\section{MATERIAL AND METHODS}

\subsection{Raw Material and Watermelon Juice}

Watermelons of the variety Crimson Sweet were purchased from the local market of Rio de Janeiro. Fruits were washed, sanitized by immersion in chlorinated water $(200 \mathrm{ppm})$ for $20 \mathrm{~min}$, manually cut and then depulped in a horizontal depulper (Model Bonina $0.25 \mathrm{df}$, Itametal, Itabuna, Brazil) equipped with a 0.6 - $\mathrm{mm}$ sieve. The juice was packed in polyethylene containers and stored at $18{ }^{\circ} \mathrm{C}$ for a maximum of three days. 


\subsection{Microfiltration and Diafiltration - Concentration and Purification}

Initially, the juice was subjected to microfiltration in order to concentrate the lycopene. Crossflow microfiltration was performed in a pilot unit comprising four tubular modules of $\alpha$-Al2O3 membranes T1-70 with a mean pore size of $0.2 \mu \mathrm{m}$ (Pall Corporation, Membralox ${ }^{\circledR}$ Ceramic Membrane Products, Port Washington, NY, USA), arranged in a series configuration, resulting in an effective permeable area of $0.022 \mathrm{~m}^{2}$. The processes were performed at $35{ }^{\circ} \mathrm{C}$ and transmembrane pressure of 2 bar (Gomes et al., 2013). Microfiltration was firstly conducted in concentration mode with the permeate being collected in a beaker placed on an electronic balance $( \pm 0.01 \mathrm{~g})$ (Marte, Model MS 20 K, São Paulo, Brazil) and the concentrate returned to the feed tank. The experiment was ended when the concentration factor $(\mathrm{CF})$ reached 6.

After reaching the desired concentration factor, using the same operating conditions, the microfiltration process was conducted in diafiltration mode in order to purify the pre-concentrated extract. The juice solutes, primarily sugars, were progressively removed by the convective flow of the distilled water used as washing fluid. The water was added to the feed tank that contained the concentrated juice obtained in the microfiltration process and the juice was microfiltred to its original volume. This was repeated until the juice soluble solids content was equal or lower than $1{ }^{\circ}$ Brix. The permeate flux data was measured during the processing and samples were collected for analysis.

\subsection{Analytical methods}

Samples of the watermelon juice and of the retained fractions of microfiltration and diafiltration were analyzed for $\mathrm{pH}$, soluble solids content ( $\left.{ }^{\circ} \mathrm{Brix}\right)$ and total titrable acidity ( $\left.\mathrm{g} 100 \mathrm{~g}-1\right)$ according to AOAC (2000).

The lycopene content was determined according to the procedure described by Sadler et al. (1990) and modified by Perkins-Veazie et al. (2001).

Antioxidant capacity was quantified according to Re et al. (1999) using the hexanic extracts obtained in the determination of the lycopene content by using ABTS radical and Trolox as standard (Gomes, 2013). The color loss was determined by spectrophotometry at $734 \mathrm{~nm}$ after $15 \mathrm{~min}$ of reaction of the sample with the ABTS radical.

Sugars composition (glucose, fructose and sucrose) was determined according to the procedure described by Macrae (1998).

Analysis of variance (ANOVA) was used to compare the means. Differences were considered significant at $\mathrm{p}<0.05$. The statistical analyses were performed with XLSTAT.

\section{RESULTS AND DISCUSSION}

The permeate flux behavior of the microfiltration/diafiltration process is shown in Figure 1. The permeate flux remained practically constant during the first $240 \mathrm{~min}$ of the microfiltration process. After this time, a slight decrease could be observed. The average permeate flux during the entire process was $69.6 \mathrm{kgh}^{-1} \mathrm{~m}^{-2}$.

Figure 1: Permeate flux during microfiltration and diafiltration processes of watermelon juice. 

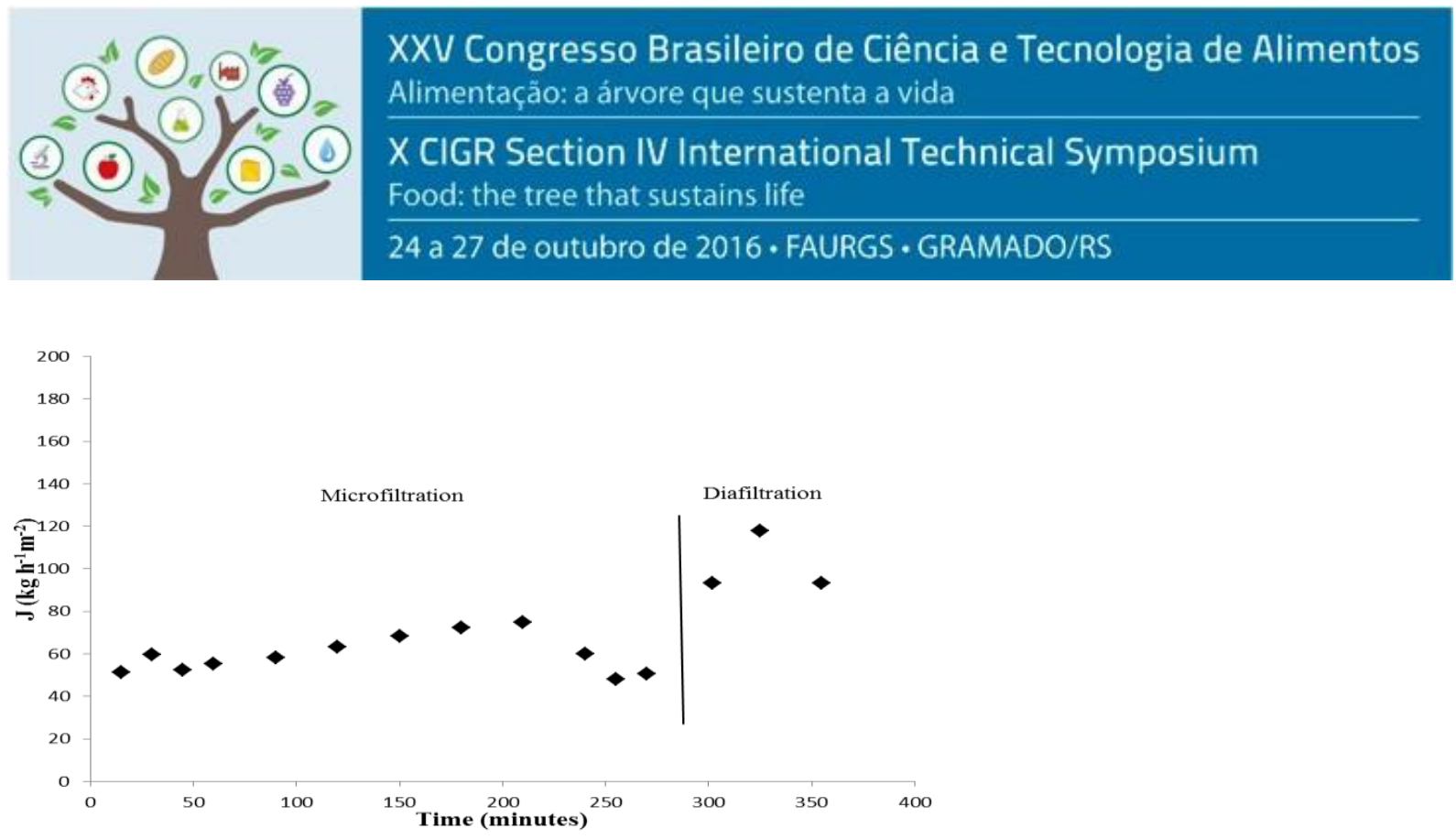

The concentration factor (CF) achieved in the microfiltration step was 5.7. In general, membrane separation processes are characterized by a flux decline along time. The causes for this behavior are concentration polarization and fouling phenomena such as adsorption, pore-blocking and deposition of solidified solutes (Van der Berg \& Smolders, 1990). At the experimental conditions used in the present work, the concentration polarization phenomena was not observed and the permeate flux remained practically stable during the first 210 min processing. Since porous membranes were used, the observed decline after this time can be attributed to phenomena related to pore adsorption, poreblocking and deposition of solutes on the membrane surface. Rai and co-workers (2010) identified the cake formation as the main reason for flux decline during microfiltration of watermelon juice.

Otherwise, the permeate flux increased to $93 \mathrm{kgh}^{-1} \mathrm{~m}^{-2}$ after 300 minutes, when the diafiltration procedure started. This technique involves washing out the original solutes (sugars, salts or other low molecular weight species) in the retentate by adding water or another solvent, resulting in dilution of the sample and decrease of its viscosity, avoiding problems related to the built up concentration boundary layer on the membrane surface, i.e, the concentration polarization and fouling.

The analytical results obtained for the feed and retentate fractions obtained in the MF/DF process are summarized in Table 1.

Table 1: Physicochemical analysis of the fractions of the microfiltration/ diafiltration process ${ }^{1}$

\begin{tabular}{|c|c|c|c|}
\hline Analysis & MFF & MFR & DFR \\
\hline Lycopene $\left(\mu \mathrm{g} \mathrm{g}^{-1}\right)^{2}$ & $40.76 \pm 0.17^{\mathrm{a}}$ & $229.77 \pm 6.86^{b}$ & $273.03 \pm 11.87^{\mathrm{c}}$ \\
\hline $\mathrm{AC}\left(\mu \mathrm{mol}\right.$ Trolox $\left.\mathrm{g}^{-1}\right)$ & $0.49 \pm 0.06^{\mathrm{a}}$ & $2.16 \pm 0.22^{b}$ & $2.27 \pm 0.09^{b}$ \\
\hline SS $\left({ }^{\circ}\right.$ Brix $)$ & $8.5 \pm 0.06^{\mathrm{a}}$ & $9.1 \pm 0.06^{\mathrm{b}}$ & $1.0 \pm 0.10^{c}$ \\
\hline Total Solids (g100 $\left.\mathrm{g}^{-1}\right)$ & $8.31 \pm 0.01^{\mathrm{a}}$ & $8.46 \pm 0.01^{\mathrm{a}}$ & $1.35 \pm 0.02^{\mathrm{b}}$ \\
\hline $\mathrm{pH}$ & $5.59 \pm 0.01^{\mathrm{a}}$ & $5.64 \pm 0.01^{\mathrm{a}}$ & $5.62 \pm 0.02^{a}$ \\
\hline TTA $\left(\mathrm{g} 100 \mathrm{~g}^{-1}\right)^{3}$ & $1.60 \pm 0.19^{\mathrm{a}}$ & $1.71 \pm 0.03^{b}$ & $1.54 \pm 0.08^{\mathrm{a}}$ \\
\hline
\end{tabular}

Same letter in the same line do not differ significantly $(\mathrm{p}>0.05)$ among themselves by Tukey test.

$1=$ Mean of three determinations

$2=$ Spectrophotometric determination

$3=$ Total acidity

MFF: Microfiltration feed juice, MFR: Microfiltration retained juice (used as Feed Diafiltration), DFR: Diafiltration retained juice, AC: Antioxidant capacity, SS; Soluble solids, TTA: Total titrable acidity

At the end of the microfiltration a rich lycopene extract was obtained. This fraction presented a lycopene content 5.6 higher than the feed juice, which was very close to the concentration factor achieved in the process, showing that the compound does not permeates the microfiltration membrane 


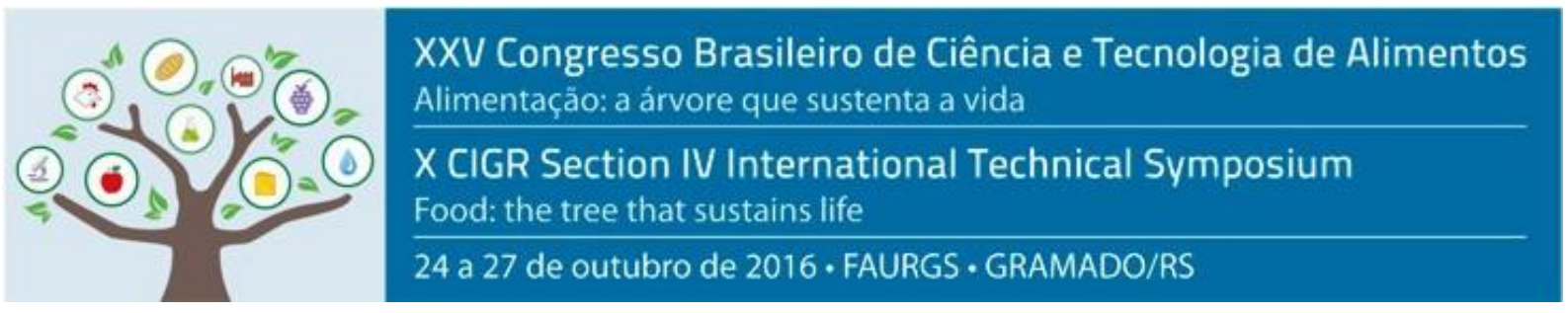

and that the lycopene content was maintained during the process. Similar results were also observed by Gomes (2013) when microfiltrated watermelon juice with $0.1 \mu \mathrm{M}$ ceramic membranes.

The antioxidant capacity of the juice fractions was also evaluated. An increase of 4.4 times in the antioxidant capacity of the fraction retained on the microfiltration was achieved when compared to the feed juice. The loss observed in relation to concentration factor can be explained due to possible lycopene oxidation or isomerization reactions, which could be minimized by carrying it out on an industrial level in a continuous system with a suitable equipment design. The concentration effect mentioned for lycopene content in the diafiltration process was not observed for the antioxidant capacity.

Regarding the physicochemical characterization, the fractions did not show large variations in $\mathrm{pH}$, total and soluble solids and total acidity in samples of the watermelon juice and the fraction concentrated by microfiltration. However, there was a drastic reduction $(\mathrm{p}<0.05)$ in the soluble solids and total solids content of the diafiltrated juice.

The results showed that microfiltration process was efficient in eliminating part of the sugars in the juice (Table 2). Although a relative concentration of 1.5, 2.2 and 1.4 times was observed for fructose, glucose and sucrose content, respectively, these values were lower than the process CF (5.7fold). This result highlights the microfiltration as an interesting process to concentrate lycopene without increasing the sugar content in the same proportion, facilitating the subsequent extract purification step.

Table 2 - Sugars content of the obtained MF/DF fractions ${ }^{1}$.

\begin{tabular}{llll}
\hline & Fructose & Glucose & Sucrose \\
\hline MFF $\left({\left.\mathrm{g} 100 \mathrm{~g}^{-1}\right)}^{\mathrm{a}}\right)$ & $2.77 \pm 0.01^{\mathrm{a}}$ & $1.07 \pm 0.00^{\mathrm{a}}$ & $1.13 \pm 0,02^{\mathrm{a}}$ \\
MFR $\left({\mathrm{g} 100 \mathrm{~g}^{-1}}^{\mathrm{a}}\right)$ & $4.05 \pm 0.06^{\mathrm{b}}$ & $2.39 \pm 0.18^{\mathrm{b}}$ & $1.63 \pm 0.08^{\mathrm{b}}$ \\
DFR $\left(\mathrm{g} \mathrm{100 \textrm {g } ^ { - 1 }}\right)$ & $0.80 \pm 0.01^{\mathrm{c}}$ & $0.64 \pm 0.01^{\mathrm{c}}$ & $0.52 \pm 0.01^{\mathrm{c}}$ \\
\hline
\end{tabular}

Same letter in the same column do not differ significantly $(\mathrm{p}>0.05)$ among themselves by Tukey test. 1 = HPLC determination, mean of three determinations

MFF: Microfiltration feed juice, MFR: Microfiltration retained juice (used as Feed Diafiltration), DFR: Diafiltration retained juice

Regarding the diafiltration step, the soluble solids content reduced approximately 8.5 times compared to the initial watermelon juice, showing that the process was effective for removal of soluble compounds, in this case, represented mainly by the sugars glucose, fructose and sucrose that decreased $71 \%, 40 \%$ and $54 \%$, respectively, when compared to the fresh juice.

Simon et al. (2002) studied the concentration of fish gelatin by ultrafiltration (UF) and its purification by means of the diafiltration technique. The authors concluded that, under appropriate conditions, it was possible to achieve a gelatin solution concentration up to $12 \%$ by weight of protein with a yield of $98 \%$. In addition, the continuous diafiltration was useful to reduce the salt content of the solution at an average speed desalination of $185 \mathrm{~g} \mathrm{~h}^{-1} \mathrm{~m}^{-2}$ with some loss of protein in the permeate side.

It is important to emphasize that after the MF/DF process the obtained product underwent a great change in its chemical composition, especially regarding to the antioxidant capacity, lycopene and sugars content characterizing it as a novel extract and not simply as a concentrated juice.

\section{CONCLUSION}

The coupling of microfiltration and diafiltration was successful in concentrating lycopene and partitioning the sugars present in watermelon juice in order to obtain a novel extract. The final extract 
presented a lycopene content and antioxidant capacity higher than the fresh juice whereas the glucose, fructose and sucrose content decreased considerably.

The high antioxidant capacity of the product indicates that it can be useful as a natural antioxidant or even for a colorant attending the consumer trends and ingredients manufactures perspectives.

\section{ACKNOWLEDGEMENTS}

Authors gratefully acknowledge CNPq for the scholarship. Authors also express their gratitude to Embrapa Food Technology for allowing conducting the experiments at its pilot plant and labs.

\section{REFERENCES}

A.O.A.C (Association of Official Analytical Chemists) (2000). Official methods of analysis, 17ed. Washington D.C.: AOAC.

BALYAN, U.; SARKAR, B. (2016). Integrated membrane process for purification and concentration of aqueous Syzygium cumini (L.) seed extract. Food and bioproducts processing, 98, 29-43.

BRASILINK. Market trends in Brazil in 2014. Avaiable in: http://brasillink.usmediaconsulting.com/2014/03/os-mercados-que-mais-crescerao-no-brasil-em-2014/. Acess: 11/24/2014.

FAO. Avaiable in: <http://faostat.fao.org/ faostat/servlet/XteServle3>. Acess: 05/22/ 2014.

GOMES, F.S.; COSTA, P. A.; CAMPOS, M. B. D.; TONON, R. V. ; COURI, S.; CABRAL, L. M. C. (2013). Watermelon juice pretreatment with microfiltration process for obtaining lycopene. International Journal of Food Science \& Technology, 48, 601-608.

HURST, W.J., 2002. Methods of Analysis for Functional Foods and Nutraceuticals - Functional Foods \& Nutraceuticals Series.CRC Press LLC, EUA.

MACRAE, R. Food Science and technology - A series of monoghraphys: HPLC in food analysis. Editora Academic Press, $2^{\mathrm{a}}$ ed., P.77, 1988.

PERKINS-VEAZIE, P.; COLLINS, J.K.; PAIR, S.D.; ROBERTS, W. (2001). Lycopene contente differs among red-fleshed watermelon cultivars. Journal of Science and Food Agriculture, 81, 983987.

RAI, C.; RAI, P.; MAJUMDAR, G. C.; DE, S.; DASGUPTA, S. (2010). Mechanism of Permeate Flux Decline during Microfiltration of Watermelon (Citrullus lanatus) Juice. Food Bioprocess Technol, 3:545-553.

RE, R., PEllegrini, N., PROTEGGEnte, A., PANNAlA, A. YANG, M., RICE-EVANS, C. (1999). Antioxidant activity applying na improved abts radical cátions decolorization assay. Free Radical Biology \& Medicine, 26, 1231-1237.

SADLER, G.; DAVIS, J.; DEZMAN, D. (1990). Rapid extraction of lycopene and b-carotene from reconstituted tomato paste and pink grapefruit homogenates. Journal of Food Science, 55: 5, 14601461.

SIMON, A.; VANDANJON, L.; LEVESQUE. G.; BOURSEAU, P. (2002). Concentration and dasalination of fish gelatin by ultrafiltration and continuos diafiltration processes. Desalination, 144, 313-318.

VAN DEN BERG and C.A. SMOLDERS (1990). Flux Decline in Ultrafiltration Processes. Desalination, 77, 101-133. 